IRA-International Journal of Management \& Social Sciences

ISSN 2455-2267; Vol.04, Issue 01 (2016)

Institute of Research Advances

http://research-advances.org/index.php/RAJMSS

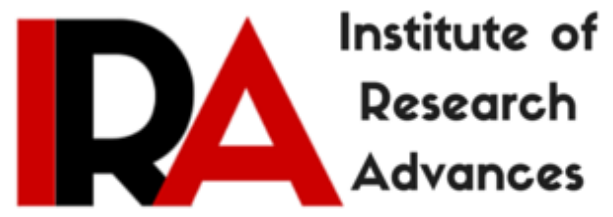

\title{
Perception of Innovative Climate, Organizational Learning and Work Motivation of Employees in Small and Medium Sized IT Companies
}

\author{
Tina Fernandes ${ }^{1},{ }^{*}$ Nandini Sanyal $^{2}$, Shubhada Ramanathan ${ }^{3}$ \\ ${ }^{1}$ Head, Dept. of Psychology, St. Francis College for Women, \\ Begumpet, Hyderabad - 500016, India. \\ ${ }^{2}$ Asst. Prof., Dept. of Psychology, St. Francis College for Women, \\ Begumpet, Hyderabad - 500016, India. \\ ${ }^{3}$ Graduate Student, St. Francis College for Women, Begumpet, \\ Hyderabad - 500016, India.
}

\#Corresponding author: Nandini Sanyal, Asst. Prof., Dept. of Psychology, St. Francis College for Women, Begumpet, Hyderabad - 500016, India.

DOI: $\underline{\text { http://dx.doi.org/10.21013/jmss.v4.n1.p23 }}$

\section{How to cite this paper:}

Fernandes, T., Sanyal, N., \& Ramanathan, S. (2016). Perception of Innovative Climate, Organizational Learning and Work Motivation of Employees in Small and Medium Sized IT Companies. IRA-International Journal of Management \& Social Sciences (ISSN 2455-2267), 4(1). doi:http://dx.doi.org/10.21013/jmss.v4.n1.p23

(C) Institute of Research Advances

\section{(c) EY-NC}

This works is licensed under a Creative Commons Attribution-Non Commercial 4.0 International License subject to proper citation to the publication source of the work.

Disclaimer: The scholarly papers as reviewed and published by the Institute of Research Advances (IRA) are the views and opinions of their respective authors and are not the views or opinions of the IRA. The IRA disclaims of any harm or loss caused due to the published content to any party. 


\section{ABSTRACT}

The objective of the present study is to determine whether there is a gender difference between employees working in small and medium sized IT companies with respect to climate for innovation, organizational learning and work motivation. The study also seeks to determine the relationship between climate for innovation, organizational learning and work motivation in employees of small and medium sized IT companies. A non-probability purposive sampling technique was employed to select a sample of 200 employees, aged between 25-35 years, out of whom 100 (50 men and 50 women) worked in small sized IT companies and 100 (50 men and 50 women) worked in medium sized IT companies. The DLOQ (Marsick \& Watkins, 2003) was administered to measure organizational learning. The climate for innovation questionnaire (Scott \& Bruce, 1994) was administered to measure the support for innovation in organizations. The WEIMS (Tremblay et al, 2009) was administered to measure work motivation. Significant differences were found between the employees of small and medium companies and also between men and women employees with respect to the dimensions of climate for innovation, organisational learning and work motivation ( $p<0.05)$. Climate for innovation, organizational learning and work motivation were found to be significantly correlated in small and medium sized companies ( $p<0.05)$. The study emphasizes the crucial importance of non-monetary factors in a company that may lead to higher job satisfaction, learning, productivity and increased performance and growth.

Keywords: corporate employees, innovative climate, organizational learning, small and medium sized companies, work motivation.

\section{INTRODUCTION}

Innovation is an essential factor for an organization's success and competitive advantage (Woodman et al., 1993). Organizations today face a dynamic environment witnessed by rapid changes in technologies, shortening of product life cycles and globalisation. In order to compete, grow and lead, organizations, especially technologically driven ones, need to be more innovative than before (Jung et al., 2003; Tierney et al., 1999). An innovative climate is defined as the shared perceptions of members of an organization pertaining to the practices, procedures and behaviours which include encouraging the development of new ideas, challenging conventional ways of doing things and learning from others inside or outside the location that stimulate the generation and realization of new ideas (Daellenbach, McCarthy \& Schoenecker, 1999). Important characterizations of innovative organizations are openness toward creativity and innovative change, support for their members in operating independently in the pursuit of new ideas and the open-mindedness for diversity among their members (Kanter, 1983; Siegel \& Kaemmerer, 1978). Other important requisites critical to innovation are adequate supplies of resources, equipment, facilities and time (Amabile, 1988; Angle, 1989; Taylor, 1963).

Organizational learning is a continuous process of generation, acquisition and integration of knowledge aimed at the development of resources and abilities that contribute to better organizational effectiveness and improvement (Argyris \& Schön, 1978; Gilley \& Maycunich, 2000; López et al., 2006). Organizational learning is not just the sum total of individual learning but is also the organization's ability to continuously augment, the collective capacity to reflect, to learn how to learn, to unlearn traditional ways of doing things and renounce old habits (Senge et al., 1999). Bates and Khasawneh (2005) collected a sample of 450 employees from 28 organizations in Jordan and observed the relationship between organizational learning culture, learning transfer climate and organizational innovation. They came to a conclusion that all three relationships were positive (Hsu, 2009).

Pinder (1998) defined work motivation as "a set of energetic forces that originate both within as well as beyond an individual's being, to initiate work-related behaviour, and to determine its form, 
direction, intensity and duration". As opposed to extrinsic motivators that have a short-term impact, intrinsic motivators tend to create a long term impact. Companies provide financial rewards in exchange for the work they expect to be completed. However, creating an environment that motivates individuals to complete additional tasks only for the enjoyment and enrichment gives them satisfying results for everyone.

According to Ryan (2000) what augments intrinsic motivation are the actions that encourage competence, such as positive feedback, freedom from undignified evaluations, optimal challenges, autonomy and communication. Extrinsic motivation emphasizes on the goal-driven reasons (Deci, 1975). The goal-driven reasons can be either monetary (like big salary increase) or nonmonetary (like wanting recognition for some activity). With respect to workplace motivation, extrinsic rewards often relate to a need to fulfil non-work related needs and work serves as the means to fulfil those needs by the salary or tangible rewards it provides (Frey \& Osterloh, 2002).

Tseng (2010) had studied the effects of learning organization practices on organizational commitment and effectiveness for small and medium-sized enterprises in Taiwan. The recommendations in the study suggested for further research along the same lines in small and medium enterprises of different industries, with different variables. Hence the rationale behind this study was to take into account these recommendations and to study a different set of variables in small and medium-sized IT companies in India. In this context, the research aims to address the following questions:

- Do employees of small and medium sized companies differ with respect to the perception of innovative climate, organizational learning and work motivation?

- Is there a relationship between perception of innovative climate, organizational learning, work motivation and their dimensions among employees of small and medium sized companies?

\section{Objectives}

1. To study whether there is an influence of the size of company (viz., small and medium) and gender (viz., men and women) on the perception of innovative climate (2 dimensions viz., support for innovation and resource supply), organizational learning (7 dimensions viz., continuous learning, inquiry and dialogue, collaboration and team learning, create systems, empower people, connect the organization and strategic leadership) and work motivation ( 2 dimensions viz., work self-determined motivation and work non-self-determined motivation).

2. To examine whether there is any relationship between perception of innovative climate, organizational learning, work motivation and their dimensions among employees of small and medium sized companies.

\section{Research Design}

\section{METHOD}

The present study adopts a between-groups design to determine whether men and women employees of small and medium companies differ with respect to the dimensions of perception of innovative climate (viz., support for innovation and resource supply), organizational learning (viz., continuous learning, inquiry and dialogue, collaboration and team learning, create systems, empower people, connect the organization and strategic leadership) and work motivation (viz., intrinsic motivation, integrated regulation, identified regulation, introjected regulation, external regulation and amotivation). This study also adopts a correlational design to determine whether there is any correlation between climate for innovation, organization learning and work motivation and their dimensions in men and women employees of small and medium sized companies. 


\section{Sample}

A non-probability purposive sampling method was used to select a sample of 200 corporate employees, out of which 100 were women, and 100 were men aged between 25 and 35 years. Participants were randomly selected from ten software companies. These were divided into 2 groups:

- Group 1: 50 men and 50 women employees from small companies.

- Group 2: 50 men and 50 women employees from medium companies.

Participants between the ages of 25 - 35 years, residing in different areas of Hyderabad were included in this sample.

\section{Instruments}

- Information Schedule

Participants were asked to provide details regarding their gender, age, education, organization details (age of the company, number of employees), function, work experience, annual income in the Information Schedule.

\section{- Climate for Innovation Measure}

The Climate for Innovation Measure was devised by Scott and Bruce (1994). The measure is a revised and extended version of the innovative climate measure developed by Siegel and Kaemmerer (1978). It is designed to assess individual differences with respect to the perception of the innovative climate in an organization. Support for innovation measures the degree to which individuals viewed the organization as open to change, supportive of new ideas from members, and tolerant of member diversity. Resource supply measures the degree to which resources (i.e., personnel, funding, time) were perceived as adequate in the organization. This scale consists of 22 personal statements to be scored on a 5-point Likert scale, with responses ranging from 'Strongly Disagree' (1) to 'Strongly Agree' (5). The questionnaire measures the attitudes of the participant in terms of the dimensions of Support for innovation and Resource supply. Cronbach's alpha for both scales were -0.92 and 0.77 respectively.

\section{- The Dimensions of the Learning Organization Questionnaire-DLOQ}

The Dimensions of the Learning Organization Questionnaire-(DLOQ) was devised by Marsick and Watkins (2003). DLOQ was designed to assess individual differences with respect to learning in an organization at an individual, team and organizational level. It consists of 43 personal statements to be answered on a 6-point Likert scale, with responses ranging from Almost Never (1) to Almost Always (6). The questionnaire measures the attitudes of the participant in terms of the dimensions of Continuous learning, Inquiry and dialogue, Collaboration and team learning, Create systems, Empower people, Connect the organization and Strategic leadership.

The commonly used estimate of internal consistency reliability tends to be 0.80 or higher for all the scales of DLOQ. Correlation coefficients were significant at the level of .001, indicating strong convergent validity of the subscales.

- Work Extrinsic and Intrinsic Motivation Scale-WEIMS

The Work Extrinsic and Intrinsic Motivation Scale is devised by Tremblay, Blanchard, Taylor and Pelletier in (2009). WEIMS is designed to assess individual differences with respect to self-determination (i.e., work self-determined and nonself-determined motivation). It consists of 18 personal statements to be scored on a 5-point Likert scale, with responses ranging from 'Strongly Disagree' (1) to 'Strongly Agree' (5). Work self-determined motivation consists of intrinsic motivation, integrated regulation and identified regulation and measures the intrinsic factors of motivation. Work non-self-determined motivation consists of introjected regulation, external regulation and amotivation and measures the extrinsic factors of motivation. Cronbach's alpha for both scales were- 0.87 and 0.56 respectively.

\section{Procedure}

After selecting the measures, a few arrangements were made for data collection. The questionnaires and the Information Schedule were prepared and organized. The authorities of small and medium sized companies were contacted to take permission for collecting data from their employees. The 
companies which gave permission for data collection were contacted. The researcher visited the companies on the scheduled dates. Rapport was established with the employees and they were made aware that their participation in the study was purely voluntary. They were assured of maintaining confidentiality through-out the study. The employees who agreed to participate in the study were requested to sign an 'Informed Consent Form'. Next, the Information Schedule was administered. The employees who met the sampling criteria were screened. On the next appointment the instructions for the questionnaires (namely, the DLOQ, Climate for Innovation and WEIMS) were given and the participants were requested to respond to the items. There was no fixed time limit for any of the questionnaires. However, the respondents were asked to complete each questionnaire in about 30 minutes.

\section{RESULTS}

Table 1 -Results of Two-Way ANOVA and descriptive statistics with size of the company and gender as the IVs and the 2 dimensions of climate for innovation, 7 dimensions of organizational learning and 2 dimensions of work motivation as the DVs.

\begin{tabular}{lccccccc}
\hline & \multicolumn{3}{c}{ Size of the Company } & \multicolumn{3}{c}{ Gender } & \multicolumn{2}{c}{ Size of the Company } \\
& \multicolumn{1}{c}{ Small } & Medium & & Men & Women & x Gender \\
\multicolumn{1}{c}{ Variables } & Mean (SD) & Mean (SD) & F & Mean (SD) & Mean (SD) & F & F \\
\hline Support for Innovation & $3.63(0.54)$ & $3.46(0.51)$ & $4.94^{*}$ & $3.46(0.56)$ & $3.64(0.48)$ & $5.97^{*}$ & 0.007 \\
Resource Supply & $3.35(0.60)$ & $3.42(0.67)$ & 0.72 & $3.32(0.67)$ & $3.46(0.60)$ & 2.41 & 0.11 \\
Continous Learning & $3.99(0.89)$ & $3.87(0.81)$ & 1.03 & $3.79(0.83)$ & $4.06(0.85)$ & $5.23^{*}$ & 0.007 \\
Inquiry and Dialogue & $4.43(0.90)$ & $4.07(0.94)$ & $8.03 * *$ & $4.11(0.92)$ & $4.40(0.93)$ & $5.01^{*}$ & 0.14 \\
Colaboration and team learning & $4.28(0.92)$ & $4.18(0.85)$ & 0.74 & $4.11(0.86)$ & $4.35(0.89)$ & $3.97^{*}$ & 2.03 \\
Systems to capture learning & $3.90(1.00)$ & $4.04(1.00)$ & 1.19 & $3.67(0.97)$ & $4.27(0.94)$ & $18.99^{* *}$ & 0.16 \\
Empower people & $4.16(0.95)$ & $4.01(0.94)$ & 1.35 & $3.92(0.96)$ & $4.26(0.91)$ & $6.64^{*}$ & 0.46 \\
Connect the organization & $4.23(0.94)$ & $4.25(0.98)$ & 0.01 & $4.05(0.95)$ & $4.44(0.92)$ & $8.62^{* *}$ & 0.04 \\
Provide strategic leadership & $4.23(1.04)$ & $4.27(1.02)$ & 0.06 & $4.04(1.04)$ & $4.46(0.98)$ & $8.28^{* *}$ & 0.26 \\
Work self-determined motivation & $11.74(1.64)$ & $11.84(1.58)$ & 0.2 & $11.65(1.61)$ & $11.94(1.60)$ & 1.61 & 0.03 \\
Work nonself-determined motivation & $8.87(1.61)$ & $9.54(1.82)$ & $7.40^{* *}$ & $9.20(1.66)$ & $9.21(1.83)$ & 0.002 & 0.005 \\
\hline
\end{tabular}

\footnotetext{
${ }^{*} \mathrm{p}<0.05$

$* * p<0.01$

df for size of the company $=1$

df for gender $=1$
}

Table 1 reveals that there is a significant difference between the employees of small and medium companies with respect to the dimension of support for innovation $(\mathrm{F}=4.94, \mathrm{p}<0.05)$. The table also shows that there is a significant gender difference with respect to the same dimension $(\mathrm{F}=5.97, \mathrm{p}<0.05)$. As is evident from the mean scores, the employees of small companies $(\mathrm{M}=3.63)$ scored significantly higher than the employees of medium companies $(\mathrm{M}=3.46)$ with respect to support for innovation. Women $(M=3.64)$ scored significantly higher than men $(M=3.46)$ with respect to support for innovation. In other words, the employees of small companies, particularly women, viewed their 
organization as more open to change and supportive of new ideas from members than the employees of medium companies.

Table 1 also reveals that there is a significant gender difference on the dimension of continuous learning $(\mathrm{F}=5.23, \mathrm{p}<0.05)$. The mean scores indicate that women $(\mathrm{M}=4.06)$ scored significantly higher than men $(\mathrm{M}=3.79)$ with respect to continuous learning. In other words, women perceived their organization as providing more opportunities for on-going education and growth, than men.

Additionally, Table 1 indicated that there is a significant difference between the employees of small and medium companies with respect to the dimension of inquiry and dialogue $(\mathrm{F}=8.03, \mathrm{p}<0.01)$. It also reveals that there is a significant difference between the men and women employees with respect to the dimension of inquiry and dialogue $(\mathrm{F}=5.01, \mathrm{p}<0.05)$. As is evident from the mean scores, the employees of small companies $(\mathrm{M}=4.43)$ scored significantly higher than the employees of medium companies $(M=4.07)$ with respect to inquiry and dialogue. Women $(M=4.40)$ scored significantly higher than men $(\mathrm{M}=4.11)$ with respect to inquiry and dialogue. In other words, the employees of small companies, particularly women, viewed their organization as more open to their views and were also allowed to inquire into the views of others, than the employees of medium companies

Moreover, the results in Table 1 reveal that there is a significant difference between the men and women employees with respect to the dimensions of collaboration and team learning $(\mathrm{F}=3.97, \mathrm{p}<0.05)$, systems to capture learning $(\mathrm{F}=18.99, \mathrm{p}<0.01)$, empower people $(\mathrm{F}=6.64, \mathrm{p}<0.05)$, connect the organization $(\mathrm{F}=8.62, \mathrm{p}<0.01)$ and provide strategic leadership $(\mathrm{F}=8.28, \mathrm{p}<0.01)$. As is evident from the mean scores, women $(\mathrm{M}=4.35, \mathrm{M}=4.27, \mathrm{M}=4.26, \mathrm{M}=4.44$, and $\mathrm{M}=4.46$ respectively) scored significantly higher than men $(\mathrm{M}=4.11, \mathrm{M}=3.67, \mathrm{M}=3.92, \mathrm{M}=4.05$, and $\mathrm{M}=4.04$ respectively) with respect to the dimension of collaboration and team learning, systems to capture learning, empower people, connect the organization and provide strategic leadership. In other words, women viewed their organization as more open to use of groups to access different modes of thinking than men. Additionally, women perceived their organization as more open to the use of technology systems utilized to share learning than men. Similarly, women perceived their organization as more open to involve them in setting and implementing a joint vision and in the decision making process than men. Moreover, women perceived their organization as more open to showing them the effect of their work, on the entire enterprise as well as the outside community than men. Lastly, women perceived their organization as has having more leaders to support learning and use learning strategically for business results, than men.

Furthermore, Table 1 indicates that there is a significant difference between the employees of small and medium companies with respect to the dimension of work non-self-determined motivation $(\mathrm{F}=7.40, \mathrm{p}<0.01)$. As is evident from the mean scores, the employees of medium companies $(\mathrm{M}=9.54)$ scored significantly higher than the employees of small companies $(M=8.87)$ with respect to the dimension of work non-self-determined motivation. In other words, employees of medium companies were more extrinsically motivated, than employees of small companies.

Lastly, Table 1 also indicates that there is no significant interaction effect of size of the company and gender on the dimensions of climate of innovation, organizational learning and work motivation. 
Table 2- Results of the correlation between the dimensions of Climate for Innovation, Organizational Learning and Work Motivation among employees of small companies $(n=100)$.

\begin{tabular}{|c|c|c|c|c|c|c|c|c|c|}
\hline & $\begin{array}{c}\text { Support } \\
\text { for } \\
\text { Innovation }\end{array}$ & $\begin{array}{c}\text { Resource } \\
\text { Supply }\end{array}$ & $\begin{array}{c}\text { Continuous } \\
\text { Learning } \\
\end{array}$ & $\begin{array}{c}\text { Inquiry and } \\
\text { Dialogue }\end{array}$ & $\begin{array}{c}\text { Collaboration } \\
\text { and Team } \\
\text { Learning } \\
\end{array}$ & $\begin{array}{c}\text { Systems to } \\
\text { Capture } \\
\text { Learning } \\
\end{array}$ & $\begin{array}{c}\text { Empower } \\
\text { People } \\
\end{array}$ & $\begin{array}{l}\text { Connect the } \\
\text { Organization }\end{array}$ & $\begin{array}{c}\text { Provide } \\
\text { Strategic } \\
\text { Leadership }\end{array}$ \\
\hline Continuous Learning & $.684^{* *}$ & $.666^{* *}$ & & & & & & & \\
\hline Inquiry and Dialogue & $.597^{* *}$ & $.339^{* *}$ & $.672^{* *}$ & & & & & & \\
\hline $\begin{array}{l}\text { Collaboration and Team } \\
\text { Learning }\end{array}$ & $.682^{* *}$ & $.551^{* *}$ & $.735^{* *}$ & $.738^{* *}$ & & & & & \\
\hline Systems to Capture Learning & $.526^{* *}$ & $.594^{* *}$ & $.648^{* *}$ & $.550^{* *}$ & $.624^{* *}$ & & & & \\
\hline Empower People & $.621^{* *}$ & $.591^{* *}$ & $.745^{* *}$ & $.653^{* *}$ & $.759^{* *}$ & $.690^{* *}$ & & & \\
\hline Connect the Organization & $.682^{* *}$ & $.616^{* *}$ & $.747^{* *}$ & $.655^{* *}$ & $.763^{* *}$ & $.743^{* *}$ & $.805^{* *}$ & & \\
\hline Provide Strategic Leadership & $.676^{* *}$ & $.614^{* *}$ & $.772^{* *}$ & $.627^{* *}$ & $.758^{* *}$ & $.727^{* *}$ & $.785^{* *}$ & $.795^{* *}$ & \\
\hline WSDM & $.352^{* *}$ & $.504^{* *}$ & $.454^{* *}$ & $.324^{* *}$ & $.420^{* *}$ & $.420^{* *}$ & $.342^{* *}$ & $.422^{* *}$ & $.433^{* *}$ \\
\hline WNSDM & -.157 & -.045 & -.094 & -.061 & .038 & -.031 & -.109 & -.096 & -.046 \\
\hline \multicolumn{10}{|l|}{$* * p<0.01$} \\
\hline \multicolumn{10}{|l|}{$*_{p}<0.05$} \\
\hline WSDM-Work self dete & otivat & & & & & & & & \\
\hline
\end{tabular}

Table 2 shows that there is a significant positive correlation between the dimension of support for innovation and the dimensions of continuous learning $(\mathrm{r}=0.68, \mathrm{p}<0.01)$, inquiry and dialogue ( $\mathrm{r}=0.59$, $\mathrm{p}<0.01)$, collaboration and team learning $(\mathrm{r}=0.68, \mathrm{p}<0.01)$, create systems to capture learning $(\mathrm{r}=0.52$, $\mathrm{p}<0.01)$, empower people $(\mathrm{r}=0.62, \mathrm{p}<0.01)$, connect the organization $(\mathrm{r}=0.68, \mathrm{p}<0.01)$ and strategic leadership $(\mathrm{r}=0.67, \mathrm{p}<0.01)$ in employees of small companies. Table 2 also indicates that there is a significant positive correlation between the dimension of resource supply and the dimensions of continuous learning $(r=0.66, p<0.01)$, inquiry and dialogue $(r=0.33, p<0.01)$, collaboration and team learning $(r=0.55, p<0.01)$, create systems to capture learning $(r=0.59, p<0.01)$, empower people $(r=0.59$, $\mathrm{p}<0.01)$, connect the organization $(r=0.61, p<0.01)$ and strategic leadership $(r=0.61, p<0.01)$ in employees of small companies. In other words, more the employees perceived the organization as providing support for innovation and resource supply, the better was the scope for organizational learning in the areas of continuous learning, inquiry and dialogue, collaboration and team learning, usage of technology to share learning, feeling of empowerment, connect the organization and strategic leadership.

Table 2 shows that there is a significant positive correlation between the dimension of support for innovation and the dimensions of work self-determined motivation $(r=0.35, p<0.01)$ in employees of small companies. The dimension of resource supply was also found to have a significant positive correlation with work self-determined motivation $(r=0.50, p<0.01)$ in employees of small companies. In other words, more the employees perceived the organization as providing support for innovation and resource supply, the better was their work self-determined motivation or intrinsic motivation.

The dimension of work self-determined motivation was found to have significant positive correlations with the dimensions of continuous learning $(\mathrm{r}=0.45, \mathrm{p}<0.01)$, inquiry and dialogue $(\mathrm{r}=0.32$, $\mathrm{p}<0.01)$, collaboration and team learning $(\mathrm{r}=0.42, \mathrm{p}<0.01)$, systems to capture learning $(\mathrm{r}=0.42, \mathrm{p}<0.01)$, 
empower people $(\mathrm{r}=0.34, \mathrm{p}<0.01)$, connect the organization $(\mathrm{r}=0.42, \mathrm{p}<0.01)$ and provide strategic leadership $(\mathrm{r}=0.43, \mathrm{p}<0.01)$ in employees of small companies. In other words, more the employees perceived the organization as supportive of organizational learning, more was their work self-determined motivation or intrinsic motivation.

The dimension of work non-self-determined motivation, was negatively correlated with the dimensions of climate for innovation (viz., support for innovation and resource supply) and the dimensions of organizational learning (viz., continuous learning, inquiry and dialogue, collaboration and team learning, systems to capture learning, empower people, connect the organization, provide strategic leadership) in employees of small companies ( $>0.05)$. However, they were not significant.

Table 3- Results of the correlation between the dimensions of Climate for Innovation, Organizational Learning and Work Motivation among employees of medium companies $(n=100)$.

\begin{tabular}{|c|c|c|c|c|c|c|c|c|c|}
\hline & \multirow[b]{2}{*}{$\begin{array}{c}\text { Support } \\
\text { for } \\
\text { Innovation }\end{array}$} & \multirow[b]{2}{*}{$\begin{array}{c}\text { Resource } \\
\text { Supply }\end{array}$} & \multirow[b]{2}{*}{$\begin{array}{c}\text { Continuous } \\
\text { Learning }\end{array}$} & \multicolumn{5}{|c|}{ Systems } & \multirow[b]{2}{*}{$\begin{array}{c}\text { Provide } \\
\text { Strategic } \\
\text { Leadership }\end{array}$} \\
\hline & & & & $\begin{array}{l}\text { Inquiry } \\
\text { and } \\
\text { Dialogue }\end{array}$ & $\begin{array}{c}\text { Collaboration } \\
\text { and Team } \\
\text { Learning }\end{array}$ & $\begin{array}{c}\text { to } \\
\text { Capture } \\
\text { Learning }\end{array}$ & $\begin{array}{c}\text { Empower } \\
\text { People }\end{array}$ & $\begin{array}{l}\text { Connect the } \\
\text { Organization }\end{array}$ & \\
\hline Continuous Learning & $.520^{* *}$ & $.546^{* *}$ & & & & & & & \\
\hline Inquiry and Dialogue & $.567^{* *}$ & $.505^{* *}$ & $.753^{* *}$ & & & & & & \\
\hline Collaboration and Team Learning & $.519^{* *}$ & $.418^{* *}$ & $.732^{* *}$ & $.747^{* *}$ & & & & & \\
\hline Systems to Capture Learning & $.416^{* *}$ & $.568^{* *}$ & $.647^{* *}$ & $.614^{* *}$ & $.597^{* *}$ & & & & \\
\hline Empower People & $.511^{* *}$ & $.576^{* *}$ & $.537^{* *}$ & $.511^{* *}$ & $.496^{* *}$ & $.724^{* *}$ & & & \\
\hline Connect the Organization & $.519^{* *}$ & $.520^{* *}$ & $.559^{* *}$ & $.581^{* *}$ & $.583^{* *}$ & $.673^{* *}$ & $.772^{* *}$ & & \\
\hline Provide Strategic Leadership & $.470^{* *}$ & $.534^{* *}$ & $.593^{* *}$ & $.572^{* *}$ & $.596^{* *}$ & $.637^{* *}$ & $.732^{* *}$ & $.795^{* *}$ & \\
\hline WSDM & .189 & $.210^{*}$ & $.392^{* *}$ & $.322^{* *}$ & $.290^{* *}$ & $.204^{*}$ & .142 & $.260^{* *}$ & $.237^{*}$ \\
\hline WNSDM & $-.301^{* *}$ & -.067 & .015 & .046 & -.053 & .044 & -.143 & -.094 & -.079 \\
\hline \multicolumn{10}{|l|}{$* * p<0.01$} \\
\hline \multicolumn{10}{|c|}{$*_{p}<0.05$} \\
\hline \multicolumn{10}{|c|}{ WSDM-Work self determined motivation } \\
\hline WNSDM-Work non self-determin & dmotivation & & & & & & & & \\
\hline
\end{tabular}

Table 3 shows that there is a significant positive correlation between the dimension of support for innovation and the dimensions of continuous learning $(\mathrm{r}=0.52, \mathrm{p}<0.01)$, inquiry and dialogue $(\mathrm{r}=0.56$, $\mathrm{p}<0.01)$, collaboration and team learning $(\mathrm{r}=0.51, \mathrm{p}<0.01)$, create systems to capture learning $(\mathrm{r}=0.41$, $\mathrm{p}<0.01)$, empower people $(\mathrm{r}=0.51, \mathrm{p}<0.01)$, connect the organization $(\mathrm{r}=0.51, \mathrm{p}<0.01)$ and strategic leadership $(\mathrm{r}=0.47, \mathrm{p}<0.01)$ in employees of medium companies. Table 2 also indicates that there is a significant positive correlation between the dimension of resource supply and the dimensions of continuous learning $(r=0.54, p<0.01)$, inquiry and dialogue $(r=0.50, p<0.01)$, collaboration and team learning $(r=0.41, p<0.01)$, create systems to capture learning $(r=0.56, p<0.01)$, empower people $(r=0.57$, $\mathrm{p}<0.01)$, connect the organization $(\mathrm{r}=0.52, \mathrm{p}<0.01)$ and strategic leadership $(\mathrm{r}=0.53, \mathrm{p}<0.01)$ in employees of medium companies. In other words, more the employees perceived the organization as providing support for innovation and resource supply, the better was the scope for organizational learning in the areas of continuous learning, inquiry and dialogue, collaboration and team learning, usage of technology to share learning, feeling of empowerment, connect the organization and strategic leadership.

Table 3 indicates that there is a significant positive correlation between the dimension of resource supply and the dimension of work self-determined motivation $(r=0.21, p<0.05)$ in employees of medium 
companies. In other words, more the employees perceived the organization as providing resources for innovation, more was their work self-determined motivation or intrinsic motivation.

The dimension of work self-determined motivation was found to have significant positive correlations with the dimensions of continuous learning $(\mathrm{r}=0.39, \mathrm{p}<0.01)$, inquiry and dialogue $(\mathrm{r}=0.32$, $\mathrm{p}<0.01)$, collaboration and team learning $(\mathrm{r}=0.29, \mathrm{p}<0.01)$, connect the organization $(\mathrm{r}=0.26, \mathrm{p}<0.01)$, systems to capture learning $(\mathrm{r}=0.20, \mathrm{p}<0.05)$ and provide strategic leadership $(\mathrm{r}=0.23, \mathrm{p}<0.05)$ in employees of medium companies. In other words, more the employees perceived the organization as supportive of organizational learning, more was their work self-determined motivation or intrinsic motivation.

Table 3 shows that there is a significant negative correlation between the dimension of support for innovation and the dimension of work non-self-determined motivation $(r=-0.30, p<0.01)$ in employees of medium companies. In other words, more the employees perceived the organization as providing support for innovation, the lesser was their work non-self-determined motivation and vice versa.

\section{DISCUSSION}

In the present study, employees of small companies scored significantly higher than the employees of medium companies with respect to the dimension of support for innovation. This is backed by previous research that in certain industry sectors, small firms contribute a high percentage of radical innovations (Abernathy \& Utterbach, 1975). Radical innovations are more likely to take place in small firms than large firms because of the advantages that small firms offer in protecting property rights (Acs, Morck, Shaver \& Yeung, 1997).

The present study found that women scored significantly higher than men with respect to the dimension of support for innovation. Innovative opportunities appear not only in 'episodic' or breakthrough product creation, but also in continuous problem-solving that is part of daily life in managing a business (Leavy, 1998; Weick \& Westley, 1996). This was particularly so for many women who started without much business experience or knowledge (only 12\% had any formal business training). The learning curve for many was steep, and they were inclined to prefer to invent their way to solutions rather than seek conventional procedures. Some approached design methodically, brainstorming a list of business ideas then choosing and refining one. Others stumbled across ideas but were judicious enough to identify and augment their potential (Fenwick, 2003).

The study shows that women scored significantly higher than men with respect to the dimension of continuous learning. Research on women refutes the causal assumptions about women's attitudes to work and career. Most women have done their learning informally, on the job, 'sitting next to Nellie' (Butler \& Connole, 1992). Studies that have investigated women's commitment to work and attitudes to workplace learning also consistently find high levels of interest in training and in mechanisms that would allow greater recognition of skills and qualification of training (Lawrence, 1994).

Employees of small companies scored significantly higher than the employees of medium companies with respect to the dimension of inquiry and dialogue. According to a report of the European Foundation for the Improvement of Living and Working Conditions (2014) "Social dialogue in micro and small companies", the study shows that social dialogue and a more participation-orientated industrial relations culture seems to demonstrate a 'high road' business model, based on the quality of the product/service delivered, as well as on solid customer orientation and satisfaction. Research indicates that employee participation through established employee representation structures may lead to the development of enhanced communication, cooperation, commitment and to the improvement of working life; and fruitful interaction between employers and employees may create trustful employment relations. 
Women were found to have scored significantly higher than men with respect to the dimension of inquiry and dialogue. From a feminist perspective, (Belenky, Clinchy, Goldberger \& Tarule, 1986) wrote of 'Women's ways of knowing' which distinguished between connected and separate knowing or forms of enquiry: separated knowing assuming a more critical eye, while connected knowing starts with an empathic, receptive eye. Feminist scholars generally have highlighted aspects of both knowing (Bigwood, 1993).

Women reported to have scored significantly higher than men with respect to the dimension of collaboration and team learning. Previous research by Woerkom \& Engen (2009) shows that team learning was significantly associated to the proportion of women in the team.

Women reported to have scored significantly higher than men with respect to the dimension of systems to capture learning. There is evidence in the area of information systems (Venkatesh \& Davis, 1996) supporting computer self-efficacy (one's judgment about one's ability to use a computer for a specific task) as a cause of perception of ease/ difficulty. According to Hofstede (1980), women rate the significance of service aspects and physical environment more highly than men. Therefore, the perceived ease of use is more prominent for women when compared to its prominence for men. Women take into account inputs from a number of sources including productivity assessments when making technology usage decisions (Venkatesh \& Morris, 2000). According to Gefen and Straub (1997) women were found to have a stronger opinion of the usefulness of software, than men. Venkatesh and Morris (2000) found that men's decisions towards using new technology were more strongly influenced by their attitude, while women were more strongly influenced by subjective norm and perceived behavioural control. Hence, there were noteworthy gender differences on the intent to use IT.

Women reported to have scored significantly higher than men with respect to the dimension of 'empower people'. Seibert, Wang and Courtright (2011) found in their study that psychological empowerment was strongly linked to vital employee attitudes such as job satisfaction and organizational commitment. Some studies indicate that women are more committed than men (Angle \& Perry, 1981; Baugh, 1990; Gould, 1975; Grusky, 1966; Hrebiniak \& Alutto, 1972).

Women have also scored higher than men with respect to the dimension of connect the organization. This would involve the organization adapting to its changing environment to meet demands, as well as the responsibilities it has towards its communities. Theorists such as Chandler (1962), Katz and Kahn (1966) and Thompson (1967) have contended that the final criterion of organizational performance is long term survival and growth. To achieve this, organizations align with their environments to remain competitive and innovative over the long run (Barnard, 1938; Lawrence \& Dyer, 1983; Lawrence \& Lorsch, 1967; Thompson, 1967; Hambrick, 1983; Summers, 1980; Jemison, 1981). Thus according to Mahmood and Hanafi (2013) entrepreneurial orientation has an affirmative effect towards business performance of women-owned SMEs. This shows that entrepreneurial oriented firms are more likely to take risks and be more innovative. This leads to an increase in performance (Ahl, 2006; Zimmerman \& Brouthers, 2012). This suggests that the firms and women owners/managers may benefit from efforts to expand their level of entrepreneurial orientation in order to survive the dynamic and complex business environment. This may be the possible reason for women connecting the organization to its environment, more than men. According to Stawiski, Deal and Gentry (2010) data from CCL's World Leadership Study indicate that: employees' perceptions of their organizations' concern for community and environment is associated to their level of organizational commitment. The data show that the relationship between CSR and commitment is stronger for women than it is for men.

Women have also scored higher than men on the dimension of provide strategic leadership. Research has associated organizational commitment to leadership behaviors that are relations-oriented and task-oriented. Relations-oriented leadership behaviors concentrates on the quality of the relationship 
with followers, whereas, task-oriented leadership behaviors has an emphasis on the task to be accomplished by followers (Bass, 1990a). Bycio, Hackett and Allen (1995) reported positive correlations between the leadership behaviors of charisma, intellectual stimulation and commitment. Women have been reported to have stronger commitment to their organizations than men (Angl \& Perry 1981). Since research has linked organizational commitment to perception of leadership, the above studies back the finding.

Employees of medium companies scored significantly higher than the employees of small companies with respect to the dimension of work non-self-determined motivation. Work non-selfdetermined motivation refers to extrinsic motivation. McMackin (2006) states that large corporations have more money, recognition and benefits to attract the best employees in comparison with SMEs (Edlund \& Nilsson, 2007). This study supports the finding that medium sized companies have more money to extrinsically reward its employees than small sized companies.

Significant positive correlations were found between the dimensions of climate for innovation and the dimensions of organizational learning in employees of small companies. A high inventive ability is attributed to small technology enterprises (Rothwell, 1989). In small enterprises an atmosphere is said to exist which is more advantageous to creative work (Acs \& Audretsch, 1991). Lines of interaction are shorter within the enterprise and between its inventors and customers. This makes it more possible that dissemination of tacit knowledge is comparably easier in small companies than in larger enterprises. It is also the case that formalised $R \& D$ departments of larger firms often neglect inventive suggestions of other employees within the enterprise, or even regard them as attacks on their reputation. Hence, smaller firms are more aware that innovation can be a very vital way to stay in the current business.

Significant positive correlations were found between the dimensions of climate for innovation and the dimensions of work self-determined motivation in employees of small companies. Research in the psychology of creativity has established that creativity is exhibited by persons who are intrinsically motivated and that creativity may be subdued in an environment with a fixed reward and control structure (e.g. Amabile, 1983). Also, Kanter (1988) has described how subdivision of large enterprises can have unfavorable effects on creativity and innovative potential. Combining these two results indicates to the conclusion that the more flexible and integrated structures of small technology companies are, in terms of tacit knowledge utilization, more favorable to creativity than the larger enterprises which are often strictly divisionalised and depend on motivation through fixed rewards and punishments. According to Koskinen and Vanharanta (2002) small enterprises sustain their advantages of better interaction and motivation, factors, which are well known enablers of tacit knowledge utilization. Furthermore, research establishes that employees working for small companies experience more satisfaction at work than employees working for a larger one (Edlund \& Nilsson, 2007). "While it is tempting to take a job offer from a large company which often can pay a higher salary and provide more resources than a smaller company, working for the little guy also has its plusses. Smaller companies often give employees more responsibility from the start, are less politicized and less bureaucratic" (The Marlin Company, 2006).

The dimension of work self-determined motivation was found to have significant positive correlations with the dimensions of organizational learning in employees of small companies. Organisational learning theorists have repeatedly contended that organisational learning is advantageous to employees because it augments feelings of inclusiveness and autonomy (Agyris \& Schon, 1978, 1996; Senge, 1990; Pedler et al., 1991). White (1959) proposed a theory notion of 'effectance motivation' where he suggested that individuals were motivated when they felt they were having an effect on the environment. Similarly, deCharms (1968) developed his theory of personal causation where he recommended that individuals were likely to be most motivated when they felt they were the authors of their own actions. Deci's (1975) theory of intrinsic motivation stated that when individuals feel 
autonomous, they are more likely to persevere with tasks and report high interest and enjoyment. Successive evidence reinforced this theory both inside the laboratory (Swann \& Pittman, 1977; Zuckerman et al., 1978; Iyengar \& Lepper, 1999) and outside of it (Lepper et al., 1993). Certainly, the evidence over the past 25 years has constantly shown that individuals who perceive their behaviours to be more under their own control than externally controlled steadily report more interest and enjoyment in such tasks, and report a willingness to persist in such tasks in the future (Deci et al., 1999).

Significant positive correlations were observed between the dimensions of climate for innovation and the dimensions of organizational learning in employees of medium companies. According to Amara, Landry, Becheikh and Ouimet (2008), the higher the need to obtain knowledge related to the learning of new skills and absorption of new equipment, the higher the degree of novelty of innovation. According to Bigliardi (2013), the financial performance of a firm and innovation has a positive relationship. Hence by this, we can conclude that financial performance has an effect on innovation and learning of a firm. And since medium sized companies have more finances, the above studies support the finding.

Significant positive correlation between the dimension of resource supply and the dimension of work self-determined motivation in employees of medium companies. Previous research shows that large companies have higher cash flows to fund innovation. They have higher assets to use as collateral for loans, particularly when capital markets may be reluctant to finance innovation (Kamien \& Schwartz, 1982; Rogers 2002). This indicates that the larger the company size, more the financial resources. This may lead to higher resource supply due to availability of funds. Previous research has already established the link between innovation and intrinsic motivation. The above study substantiates the same.

The dimension of work self-determined motivation was found to have significant positive correlations with the dimensions of continuous learning, inquiry and dialogue, collaboration and team learning, connect the organization, systems to capture learning and provide strategic leadership in employees of medium companies. According to previous research, large firms may have access to a widespread range of knowledge and human capital skills than small firms, allowing higher rates of innovation (Granstrand \& Sjölander, 1990; Mourrouti, Cilkin \& Dunton, 1999). Organisational learning theorists have often argued that organisational learning is advantageous to employees because it augments feelings of inclusiveness and autonomy (Agyris \& Schon, 1978, 1996; Senge, 1990; Pedler et al., 1991). And an increase in autonomy leads to increase in intrinsic motivation. Hence the above studies back this finding.

Finally, the study reported significant negative correlation between the dimension of support for innovation and the dimension of work non-self-determined motivation in employees of medium companies. According to Galia (2007) extrinsic incentives become less important as motivators when specific work assignments or organization's goals and values are regarded as part of employees' selfconcept, defined as growth and development, and as a way of asserting and challenging personal capabilities, task accomplishment becomes an end in itself.

Many SMEs recognize the importance of organizational learning and realize that learning results in changes in organizational values and promotes a fundamental transformation of the organization so it becomes more successful and productive (Argyris \& Schön, 1996). Success for SMEs would involve creating an innovative climate and fostering organizational learning that would have a positive impact on employee morale and motivation. Thus, understanding the employees' perceptions of climate for innovation, organizational learning and work motivation in SMEs' will have significant implications for enterprise stockholders, managers, employees, customers and the community in which SMEs operates (Wolff \& Pett, 2006). Lastly, this study has both theoretical and practical implications for HRD research and practice about climate for innovation, organizational learning and work motivation. Because formal HRD is more likely to be found in large organizations, little research has been conducted on HRD in 
SMEs. The results of this study provide valuable suggestions and implications for human resource professionals and managers to understand the present status, differences, and relationships in climate for innovation, organization learning and work motivation in Indian companies, particularly in the IT sector.

\section{REFERENCES}

Acs, Z. J., Morck, R., Shaver, J. M., \& Yeung, B. (1997). The internationalization of small and mediumsized enterprises: A policy perspective. Small business economics, 9(1), 7-20.

Acs, Z.J., Audretsch, D.B., 1991. Innovation and Small Firms. Palatino, Hong Kong.

Ahl, H. (2006). Why research on women entrepreneurs needs new directions. Entrepreneurship Theory and Practice, 30(5), 595-621.

Amabile TM. The social psychology of creativity. New York: Springer-Verlag; 1983.

Amabile, T. 1988. A model of creativity and innovation in organizations. In B. M. Staw \& L. L. Cummings (Eds.), Research in organizational behaviour, vol. 10: 123-167. Greenwich, CT: JAI Press.

Amara, N., Landry, R., Becheikh, N., \& Ouimet, M. (2008). Learning and novelty of innovation in established manufacturing SMEs. Technovation,28(7), 450-463.

Angle, H. 1989. Psychology and organizational innovation. In A. Van de Ven, H. Angle, \& M. Poole (Eds.), Research on the management of innovation: The Minnesota studies: 135-170. New York: Harper \& Row.

Angle, H. L., \& Perry, J. L. (1981). An empirical assessment of organizational commitment and organizational effectiveness. Administrative science quarterly, 1-14.

Argyris, C. and Schön, D. (1996) Organizational learning II: Theory, method and practice, Reading, Mass: Addison Wesley.

Argyris, C., \& Schön, D. (1978) Organizational learning: A theory of action perspective, Reading, Mass: Addison Wesley.

Barnard, C. I. (1938). The economy of incentives. Classics of organization theory, 93-102.

Bass, B. (1990a). Bass \& Stogdill's Handbook of Leadership (3rd ed.). New York: The Free Press.

Bates, R., \& Khasawneh, S. (2005). Organizational learning culture, learning transfer climate and perceived innovation in Jordanian organizations. International journal of training and development, 9(2), 96-109.

Baugh, S. G. (1990). Gender influences on organizational commitment. In Proceedings of the Southern Management Association (Vol. 20, pp. 204-206). Mississippi State, MS: Southern Management Association.

Belenky, M., Clinchy, B. M., Goldberger, N. R., \& Tarule, J. (1986). Women's ways of knowing: The development of self, mind, and voice. New York: Basic Books. Billeh, V. \& Hasan, O.(1975). Factors affecting teachers' gain in understanding the nature of science. Journal of Research in Science Teaching, 12, 209-219.

Bigliardi, B. (2013). The effect of innovation on financial performance: A research study involving SMEs. Innovation, 15(2), 245-255.

Bigwood, C. (1993). Earth muse: Feminism, nature, and art.

Butler, E., \& Connole, H. (1992). Sitting next to Nellie. What Future for Technical and Vocational Education.

Bycio, P., Hackett, R., \& Allen, J. (1995). Further assessment's of Bass's (1985) conceptualization of transactional and transformational leadership. Journal of Applied Psychology, 80, 468-478.

Chandler, A. D. (1962). Strategy and structure: The history of American industrial enterprise. MIT Press, Cambridge, Mass.(1977) The Visible Hand, Harvard University Press, Cambridge, Mass.(1980) The Growth of the Transnational Industrial Firm in the United States and the United Kingdom: a Comparative Analysis', Economic History Review, 33, 396-410. 
Chung, J., \& Monroe, G. S. (2003). Exploring social desirability bias. Journal of Business Ethics, 44, 291-302.

Daellenbach, U. S., McCarthy, A. M., \& Schoenecker, T. S. (1999). Commitment to innovation: The impact of top management team characteristics. R\&D Management, 29(3), 199-208.

DeCharms, R.C. (1968). Personal causation; The internal affective determinants of behavior. New York: Academic Press...Deci, E. L. (1975). Intrinsic motivation. New York and London.

Deci, E. L., \& Ryan, R. M. (1975). Intrinsic motivation. John Wiley \& Sons, Inc..

Deci, E. L., Koestner, R., \& Ryan, R. M. (1999). A meta-analytic review of experiments examining the effects of extrinsic rewards on intrinsic motivation. Psychological bulletin, 125(6), 627.

Edlund, M., \& Nilsson, H. (2007). Employee Motivation in Medium-sized Manufacturing Enterprises (Doctoral dissertation, Master thesis. Online. Available from: http://epubl. ltu. se/1402-1552/2007/017/LTU-DUPP-07017-SE.

European Foundation for the Improvement of Living and Working Conditions. (2014). Social dialogue in micro and small companies. Dublin: Author

Fenwick, T. (2003). Innovation: examining workplace learning in new enterprises. Journal of workplace learning, 15(3), 123-132.

Galia, F. (2007). Intrinsic-extrinsic motivations, knowledge sharing and innovation in French firms. Organizational innovation: the dynamics of organizational capabilities and design, 1-29.

Gefen, D., and Straub, D. W. "Gender Differences in the Perception and Use of E-mail: An Extension to the Technology Acceptance Model," MIS Quarterly (21:4), 1997, pp. 389-400.

Gilley, J. W., \& Maycunich, A. (2000). Organizational learning, performance, and change: An introduction to strategic human resource development. Cambridge, MA: Perseus.

Gould, S. B. (1975). Organizational identification and commitment in two environments. Unpublished doctoral dissertation, Michigan State University, Lansing.

Granstrand, O., \& Sjölander, S. (1990). Managing innovation in multi-technology corporations. Research Policy, 19(1), 35-60.

Grusky, O. (1966). Career mobility and organzational commitment.Administrative Science Quarterly, 488-503.

Hambrick, D. C. (1983) Some tests of the effectiveness and functional attributes of Miles and Snow's strategic types. Academy of Management Journal, 26, 5-26.

Hofstede, G. Culture's Consequences: International Differences in Work Related Values, Sage, London, 1980.

Hrebiniak, L. G., \& Alutto, J. A. (1972). Personal and role-related factors in the development of organizational commitment. Administrative science quarterly, 555-573.

Hsu, H.Y. (2009). Organizational learning culture's influence on job satisfaction, organizational commitment, and turnover intention among $\mathrm{R} \& \mathrm{D}$ professionals in Taiwan during an economic downturn, University of Minesota. 16-37.

Msmehyd.ap.nic.in/Definitions.htm

M1creativity.co.uk/innovationclimate.htm

Iyengar, S. S., \& Lepper, M. R. (1999). Rethinking the value of choice: a cultural perspective on intrinsic motivation. Journal of personality and social psychology, 76(3), 349.

Jemison, D. B. (1981). Organizational versus environmental sources of influence in strategic decision making. Strategic Management Journal, 2(1), 77-89.

Jung DI, Chow $\mathrm{C}, \mathrm{Wu}$ A. The role of transformational leadership in enhancing organizational innovation: hypotheses and some preliminary findings. Leadership Quarterly 2003;14:525-44.

Kamien, M. I., \& Schwartz, N. L. (1982). Market structure and innovation. Cambridge University Press.

Kanter, R. 1983. The change masters. New York: Simon \& Schuster.

Kanter, R. 1988. When a thousand flowers bloom: Structural, collective, and social conditions for innovation in organizations. In B. M. Staw \& L. L. Cummings (Eds.), Research in organizational behavior, vol 10: 169-211. Greenwich, CT: JAI Press.

Katz, D., \& Kahn, R. L. (1966). The psychology of organizations. New York: HR Folks International. 
Koskinen, K. U., \& Vanharanta, H. (2002). The role of tacit knowledge in innovation processes of small technology companies. International journal of production economics, 80(1), 57-64.

Lawrence, K. (1994) 'Valuing women: new approaches to/for the training reform agenda', in (re)Forming Post-Compulsory Education and Training: Reconciliation and Reconstruction, Conference Proceedings Vol. 1, Centre for Skill Formation Research and Development, Griffith University, Brisbane.

Lawrence, P. R., \& Dyer, D. (1983) Renewing American industry. New York: Free Press

Lawrence, P. R., \& Lorsch, J. W. (1967) Organization and environment: Managing differentiation and integration. Boston: Harvard University.

Leavy, B. (1998). The concept of learning in the strategy field review and outlook. Management Learning, 29(4), 447-466.

Lepper, M. R., Woolverton, M., Mumme, D. L., \& Gurtner, J. (1993). Motivational techniques of expert human tutors: Lessons for the design of computer-based tutors. Computers as cognitive tools, 1993, 75-105.

Löfqvist, H., Barbouti, A., Tariq, M., \& Sällberg, H. (2014). The preference between salary increase and more vacation time.

López, S. P., Peón, J. M. M., \& Ordás, C. J. V. (2006). Human resource management as a determining factor in organizational learning. Management Learning, 37(2), 215-239.

Mahmood, R., \& Hanafi, N. (2013). Entrepreneurial orientation and business performance of womenowned small and medium enterprises in Malaysia: Competitive advantage as a mediator. International Journal of Business and Social Science, 4(1).

Malone, T. W. (1981). Toward a theory of intrinsically motivating instruction.Cognitive science, 5(4), 333-369.

Marquardt, M. J., \& Kearsley, G. (1998). Technology-based learning: Maximizing human performance and corporate success. CRC Press.

Marsick, V. J., \& Watkins, K. E. (2003). Demonstrating the value of an organization's learning culture: the dimensions of the learning organization questionnaire. Advances in developing human resources, 5(2), 132-151.

McMackin, E. (2006). The lure of small, National Federation of Independent Business.

Mourouti, O., Culkin, N., \& Dunton, H. (1999). On Innovation Debate: Small Vs Large or Small with Large? (No. 1999: 16).

Osterloh, M., \& Frey, B. S. (2002). Does pay for performance really motivate employees. Business performance measurement: theory and practice. Cambridge University Press, New York, New York, USA, 107-122.

Paolillo, J., \& Brown, W. 1978. How organizational factors affect R\&D innovation. Research Management, 21: 12-15.

Pedler,M., Burgoyne, J. \& Boydell, T. (1991) The Learning Company: a strategy for sustainable development (London, McGraw-Hill).

Pinder CC. 1998. Work Motivation in Organizational Behavior. Upper Saddle River, NJ: Prentice Hall.

Randall, D. M., \& Fernandes, M. F. (1992). Social desirability bias in ethics research. Business Ethics Quarterly, 2(2), 183-205.

Rogers, M. (2002). The influence of diversification and market structure on the R\&D intensity of large Australian firms. Australian Economic Review,35(2), 155-172.

Rothwell, R., 1989. SME's Inter-firm relationships and technological change. Entrepreneurship and Regional Development, 1.

Ryan, R. M., \& Deci, E. L. (2000). Intrinsic and extrinsic motivations: Classic definitions and new directions. Contemporary educational psychology, 25(1), 54-67.

Ryan, R. M., \& Deci, E. L. (2000). Self-determination theory and the facilitation of intrinsic motivation, social development, and well-being.American psychologist, 55(1), 68.

Samad, S. (2003). The Differential Effects of Creative Organizational Climate and Organizational Commitment on Learning Organization, Universitiy Teknologi MARA, Malaysia, 3. 
Scott, S. G., \& Bruce, R. A. (1994). Determinants of innovative behavior: A path model of individual innovation in the workplace. Academy of management journal, 37(3), 580-607.

Seibert, S. E., Wang, G., \& Courtright, S. H. (2011). Antecedents and consequences of psychological and team empowerment in organizations: a meta-analytic review. Journal of Applied Psychology, 96(5), 981.

Senge, P. M. (1990). The art and practice of the learning organization (pp. 3-11). New York: Doubleday.

Senge, P., Kleiner, A., Roberts, C., Ross, R., Roth, G. and Smith, B. (1999) The Dance of Change. New York: Doubleday.

Siegel, S., \& Kaemmerer, W. 1978. Measuring the perceived support for innovation in organizations. Journal of Applied Psychology, 63: 553-562.

Smallbusiness.chron.com/definition-intrinsic-motivation-workplace-10952.html

Stawiski, S., Deal, J. J., \& Gentry, W. (2010). Employee perceptions of corporate social responsibility. Center for Creative Leadership, Greensboro, NC.

Summers, E. (1980) Strategic behavior in business and government. Boston: Little, Brown.

Swann Jr, W. B., \& Pittman, T. S. (1977). Initiating play activity of children: The moderating influence of verbal cues on intrinsic motivation. Child development, 1128-1132.

Taylor, C. 1963. Variables related to creativity and productivity in men in two research laboratories. In C. Taylor \& R. Barron (Eds.), Scientific creativity: Its recognition and development: 513-597. New York: Wiley.

The Marlin Company. (2006) Goofing off at work, The Marlin Company.

Thompson, J. D. (1967) Organizations in action. New York: McGraw-Hill.

Tierney P, Farmer SM, Graen GB. An examination of leadership and employee creativity: the relevance of traits and relationships. Personnel Psychology 1999;52:591-620.

Tremblay, M. A., Blanchard, C. M., Taylor, S., Pelletier, L. G., \& Villeneuve, M. (2009). Work Extrinsic and Intrinsic Motivation Scale: Its value for organizational psychology research. Canadian Journal of Behavioural Science/Revue canadienne des sciences du comportement, 41(4), 213.

Tseng, C. C. (2010). The effects of learning organization practices on organizational commitment and effectiveness for small and medium-sized enterprises in Taiwan (Doctoral dissertation, UNIVERSITY OF MINNESOTA).

Utterback, J. M., \& Abernathy, W. J. (1975). A dynamic model of process and product innovation. Omega, 3(6), 639-656.

Van Der Vegt, G. S., Van de Vliert, E., \& Huang, X. (2005). Location-level links between diversity and innovative climate depend on national power distance. Academy of Management Journal, 48(6), 1171-1182.

van Woerkom, M., \& van Engen, M. L. (2009). Learning from conflicts? The relations between task and relationship conflicts, team learning and team performance. European Journal of Work and Organizational Psychology,18(4), 381-404.

Venkatesh, V. "Determinants of Perceived Ease of Use: Integrating Control, Intrinsic Motivation, and Emotion Into the Technology Acceptance Model," Information Systems Research, forthcoming.

Venkatesh, V., \& Morris, M. G. (2000). Why don't men ever stop to ask for directions? Gender, social influence, and their role in technology acceptance and usage behavior. MIS quarterly, 115-139.

Venkatesh, V., and Davis, F. D. "A Model of the Perceived Ease of Use Development and Test," Decision Sciences (27:3), 1996, pp. 451-481.

Watkins, K. E., \& Marsick, V. J. (1993). Sculpting the learning organization: Lessons in the art and science of systemic change. Jossey-Bass Inc., 350 Sansome Street, San Francisco, CA 941041310.

Weick, K. E., \& Westley, F. (1996). Organizational learning: Affirming an oxymoron. Sage: London, 440-458.

White, R. W. (1959). Motivation reconsidered: the concept of competence. Psychological review, 66(5), 297. 
Wolff, J. A., \& Pett, T. L. (2006). Small-firm performance: Modeling the role of product and process improvements. Journal of Small Business Management, 44(2), 268-284.

Woodman RW, Sawyer JE, Griffin RW. Toward a theory of organizational creativity. Academy of Management Review 1993;18(2):293-321.

Zerbe, W. J., \& Paulhus, D. L. (1987). Socially desirable responding in organizational behavior: A reconception. Academy of Management Journal, 12(2), 250-264.

Zimmerman, M.A. \& Brouthers, K.D. (2012). Gender heterogeneity, entrepreneurial orientation, and international diversification. International Journal of Gender and Entrepreneurship, 4(1), 20-43.

Zuckerman, M., Porac, J. F., Lathin, D., Smith, R., \& Deci, E. L. (1978). On the importance of selfdetermination for intrinsically motivated behavior. Personality and Social Psychology Bulletin, 4, 443-446. 